\title{
Tatar Language Policies in Comparative Perspective: Why Some Revivals Fail and Some Succeed
}

\author{
Dmitry Gorenburg \\ gorenbur@alumni.princeton.edu
}

Davis Center for Russian and Eurasian Studies

Harvard University

March 2005 


\section{Introduction}

For minority nationalist activists at the dawn of perestroika, the decline of titular languages was one of the most pressing problems facing their republics. By the late 1980s in the urban areas of most Soviet republics, minority languages had been largely supplanted by Russian. ${ }^{1}$ Members of minority ethnic groups used the Russian language in public more than they used their "native" languages. To some extent, this was the case at home as well, especially among younger cohorts. (Grenoble 2003, 193-7) The fear of continuing language shift was one of the main mobilizing factors in the nationalist movements that developed in virtually all ethnic regions of the Soviet Union in the late 1980s. (Beissinger 2002, Gorenburg 2003) While the political success of these movements varied greatly, all of the former union republics of the Soviet Union and a majority of the former autonomous republics undertook language revival programs after independence. This occurred even in those regions where former Communist elites retained power in the 1990s. (Gorenburg 1999)

In this paper, I seek to examine the extent to which government-sponsored language revival programs are able to change the language use situation in a region that is part of a large state with a different majority language. For this reason, I focus on Tatarstan, one of the ethnic republics that remained a part of Russia and did not become independent in 1991. Given its status as part of the Russian Federation and the even split between Tatars and Russians in the republic population, Tatarstan presents a good case for examining the extent to which government efforts to revive a language can succeed in a situation where another language continues to be widely spoken and is perceived by a

\footnotetext{
${ }^{1}$ I use the term minority to refer to the groups' status within the Soviet Union as a whole. Some of the groups comprised majorities of the population of "their" territorial homelands.
} 
large part of the population as more prestigious and more useful than the language being revived.

I examine the process of language revival in Tatarstan in the context of the eightstage Graded Intergenerational Disruption Scale (GIDS) devised by Joshua Fishman.

(Fishman 1991, 87-109) This scale measures the extent to which intergenerational language transmission has been disrupted by looking at the extent to which the threatened language is used in various private and public contexts. GIDS stages 6-8 address the extent to which a language continues to be spoken in the home. Stage 5 addresses literacy, stage 4 focuses on compulsory education, stage 3 on the work environment (including interaction with speakers of the majority language), and stages 1-2 include the use of the language in government and media.

The first section of the article examines the extent to which language shift had occurred in Tatarstan at the end of the Soviet period. The second section traces the efforts of the Tatarstan government to revive the language, while the third section addresses the extent to which these efforts were successful in reversing Tatar to Russian language shift. Finding that these efforts have not been as successful as cultural activists and government language planners had hoped, I make a preliminary effort to examine possible causes of success or failure of language revival programs in minority ethnic regions by comparing language revival in Tatarstan to similar, but far more successful programs in Spain.

\section{Status Quo Ante: The Language Situation in Tatarstan at the dawn of perestroika ${ }^{2}$}

When the Tatar nationalist movement was being established in 1988-89, the members of the Tatar cultural elite that served as its founders blamed the Soviet

\footnotetext{
${ }^{2}$ In this article, I focus on the extent to which the Tatar language was used in various contexts at various points in time. I do not examine the extent to which the language had incorporated borrowings from Russian, nor do I examine the phenomenon of code-switching among Tatar-speakers. Suzanne Wertheim has done excellent work on these topics. (Wertheim 2003a, 2003b, 2005)
} 
government primarily for the decline of Tatar culture and language. They noted that the Tatar language was being used less than at any time in modern history, pointing out that the number of books and newspapers being published in Tatar annually in the late 1980s was lower than the number published in 1913. Furthermore, they noted that Tatar had been virtually excluded from the public sphere in Tatarstan. It was not used in government except in a few rural districts, in public transport, or in higher education. While the Tatar-language primary and secondary education system that had been established in the 1920s continued to function, it had largely been relegated to rural areas and virtually all Tatar children in urban areas were being educated in Russian. Tatars were expected to use Russian in public, especially in spheres where Russians were present such as stores, on the street, and in public transport. In many cases, Tatars speaking the Tatar language amongst themselves while riding on a bus or walking along the street were told by passing Russians to stop using that language in public. The combination of state policy aimed at reducing the spheres in which the Tatar language was used and the potential that someone speaking Tatar in public might face condemnation from passerby ensured that the Tatar language was rapidly disappearing from the public sphere and was also being used less in private settings.

Although Soviet censuses continued to show that the Tatar language retained a dominant position among ethnic Tatars, the reality was more complicated. While 96.6 percent of Tatars living in Tatarstan claimed Tatar as their native language in the 1989 census, a decrease of only one percent from the previous census in 1979, it has been widely recognized that in Soviet censuses, the response to the native language question 
usually represented simply a restatement of the respondent's ethnicity. ${ }^{3}$ (Silver 1986) The extent to which Tatars had come to use the Russian language in various contexts is better analyzed through sociolinguistic surveys. A number of which were carried out in Tatarstan in the mid-1980s and early 1990s. These surveys provide us with the status quo ante that shows both the extent to which the concerns of Tatar activists were valid and the extent to which the Tatarstan government was successful in reversing linguistic assimilation through the language revival program described in section two of this paper.

Taken as a whole, these surveys show that while the Tatar language remained dominant in Tatar populated rural districts, a large number of urban Tatars had switched to Russian as their primary language of communication, both at work and at home. Thus a 1990 survey showed that about 10 percent of urban Tatars considered both Russian and Tatar to be their native languages, ${ }^{4}$ with four percent claiming Russian and the remaining 86 percent Tatar. The same survey showed that while 97.4 percent of rural Tatars could speak, read and write Tatar fluently, only 65.1 percent of urban Tatars had the same level of facility with the Tatar language. By comparison, 84 percent of urban Tatars were fluent in Russian. Another 23.3 percent of urban Tatars said that they were fluent speakers of the language but could read and write it only with difficulty. As for the rest, 7.8 percent noted that they spoke Tatar only with difficulty, 2.7 percent could understand it but did not speak the language, and a final 1.1 percent said that they did not know any Tatar whatsoever. The number of Tatar speakers was even lower in Kazan, the capital of

\footnotetext{
${ }^{3}$ Throughout the paper, the term "native language” refers to the Russian term rodnoi iazyk, which does not necessarily imply actual ability to speak the language. Native language, as used in this context, is often simply a statement of the respondent's linguistic identity, which usually (but not always) mirrors his/her ethnic identity.

${ }^{4}$ Researchers from the Tatarstan Institute of Language, Literature and History conducted the survey discussed in this paragraph. They surveyed 1000 Russian and 1000 Tatar respondents from 12 cities and towns throughout Tatarstan. A second survey examined language use among 800 Tatars in Kazan. For more on the methodology of the surveys, see Iskhakova (2001, 9-10)
} 
Tatarstan, as compared to other urban areas in the republic. In Kazan, just over half of the respondents said they were fully fluent in Tatar, and almost 30 percent were unable to speak the language or spoke it only with difficulty. (Iskhakova 2001, 39-40)

Given that most Tatars worked in ethnically mixed environments and few Russians spoke Tatar, it was not surprising that Tatars tended to use Russian or to mix languages in the workplace. However, Tatars tended to speak Russian at work even when conversing with other Tatars (Table 1). Furthermore, Russian had become the dominant language among urban Tatars in most private contexts as well. As shown in table 1, urban Tatars continue to speak Tatar with their parents, Russian played a much bigger role in other contexts, and particularly when speaking with children. Furthermore, 46.5 percent of Tatar children spoke Russian exclusively among themselves, while only 19.4 percent spoke Tatar. The rest used both languages. (Iskhakova 2001, 43) The survey also showed that even Tatars who spoke Tatar at home and at work received information from Russian sources. Again, in the capital city of Kazan, the position of the Tatar language was slightly weaker in all contexts than in the other Tatarstani cities (Table 2).

Table 1. Language use among urban Tatars, by context (1990)

\begin{tabular}{llllllll}
\hline & $\begin{array}{l}\text { With } \\
\text { parents }\end{array}$ & $\begin{array}{l}\text { With } \\
\text { spouse }\end{array}$ & $\begin{array}{l}\text { With preschool- } \\
\text { aged children }\end{array}$ & $\begin{array}{l}\text { With older } \\
\text { children }\end{array}$ & $\begin{array}{l}\text { At work } \\
\text { with Tatars }\end{array}$ & $\begin{array}{l}\text { Reading } \\
\text { newspapers }\end{array}$ & $\begin{array}{l}\text { Watching } \\
\text { TV }\end{array}$ \\
\hline Tatar & 72.9 & 57.8 & 32.5 & 26.2 & 29.1 & 14.1 & 9.8 \\
Both & 18.2 & 22.1 & 36.6 & 40.7 & 36.0 & 36.3 & 75.6 \\
Russian & 8.6 & 19.9 & 30.8 & 33.0 & 34.8 & 49.6 & 14.6 \\
\hline
\end{tabular}

Source: Iskhakova 2001, 42-4, 50.

Table 2. Language use among Kazan Tatars, by context (1990)

\begin{tabular}{lccccccc}
\hline & $\begin{array}{l}\text { With } \\
\text { parents }\end{array}$ & $\begin{array}{c}\text { With } \\
\text { spouse }\end{array}$ & $\begin{array}{l}\text { With preschool- } \\
\text { aged children }\end{array}$ & $\begin{array}{l}\text { With older } \\
\text { children }\end{array}$ & $\begin{array}{l}\text { At work } \\
\text { with Tatars }\end{array}$ & $\begin{array}{l}\text { Reading } \\
\text { newspapers }\end{array}$ & \multicolumn{2}{c}{ Watching } \\
\hline Tatar & 66.8 & 52.0 & 30.7 & 24.8 & 26.0 & 11.1 & 9.8 \\
Both & 20.6 & 22.0 & 33.7 & 38.6 & 32.6 & 30.9 & 69.2 \\
Russian & 12.6 & 26.0 & 35.6 & 36.6 & 41.4 & 58.1 & 21.1 \\
\hline
\end{tabular}

Source: Iskhakova 2001, 59, 62. 
The extent to which urban Tatars used Tatar versus Russian depended on several factors, including the language in which they were educated, their age, and whether they had been born in the city or in a rural area. Surveys conducted in several cities in the mid1980s show the extent to which these factors affect the use of Tatar in various settings. ${ }^{5}$ Language of education was a particularly important factor. Whereas over half of Tatars educated in the Tatar language used it exclusively with their Tatar friends, just over a third of those educated in both languages and only about one-seventh of Tatars educated in Russian did so. Similarly, respondents educated in Tatar were almost five times more likely to speak Tatar at work than those educated in Russian (Table 3). Younger Tatars were more likely than older ones to use the Russian language in various personal contexts, including speaking with parents, spouses, and children. (Sharypova 1989, 80-4) Similarly, Tatars born in rural areas were 2.5 times more likely to speak Tatar both with friends and at work than those born in the city. (Sharypova 1989, 85-6) At the same time, the length of time a person had lived in the city did not seem to have an appreciable effect on the likelihood of using the Tatar language in various contexts. (Sharypova 1989, 8796)

Table 3. Language use among urban Tatars by language of education (1985)

\begin{tabular}{lccc|ccc|ccc}
\hline Language of education & \multicolumn{3}{c}{ Tatar } & \multicolumn{3}{c|}{ First Tatar then Russian } & \multicolumn{3}{c}{ Russian } \\
\hline Language used & \multicolumn{2}{c}{ Tatar Both Russian } & Tatar & Both & Russian & \multicolumn{2}{|c}{ Tatar Both Russian } \\
With friends & 50.9 & 45.6 & 3.5 & 36.8 & 60.5 & 2.6 & 13.7 & 61.8 & 23.6 \\
At work & 36.7 & 53.3 & 9.7 & 31.8 & 54.4 & 13.2 & 7.5 & 63.4 & 28.9 \\
Listen to radio & 5.4 & 90.3 & 4.2 & 1.0 & 94.2 & 4.8 & 0 & 73.1 & 26.8 \\
Read literature & 16.9 & 81.0 & 8.0 & 6.6 & 76.9 & 16.0 & 1.5 & 24.5 & 67.9 \\
Read newspapers & 6.6 & 86.3 & 7.1 & 0 & 76.3 & 23.6 & 0 & 32.5 & 67.5 \\
Write letters & 56.9 & 33.7 & 4.3 & 40.4 & 45.7 & 13.8 & 5.9 & 24.5 & 65.4 \\
\hline
\end{tabular}

Source: Sharypova 1989, 114-16.

\footnotetext{
${ }^{5}$ Unfortunately, the authors of the survey did not use modern statistical methods, so it difficult to determine how these factors correlate with each other or which ones might show statistical significance in a multivariate regression. See Sharypova $(1989,68-75)$ for a discussion of this survey’s methodology.
} 
Obviously, factors such as age, language of education and place of birth are all highly correlated, given that the availability of Tatar language education had declined over time during the late Soviet period and has always been more widely available in rural areas, and that younger Tatars are somewhat more likely to have been born in the city than their elders given the low proportion of Tatars in urban areas prior to the 1960s. While the available information does not allow one to determine the relative significance of these factors vis-à-vis each other, it is clear that some combination of native language education, rural origin, and age explain a great deal of the variation in language use among urban Tatars.

In terms of the GIDS scale, Tatar was almost entirely unused in stages 1-3. In urban areas, government services were not available in Tatar. ${ }^{6}$ Even in Tatar villages, where village council meetings often used the Tatar language, official records and correspondence with other government agencies took place in Russian. There were a number of Tatar newspapers and a minimal level of Tatar television and radio broadcasting, but these were of relatively low quality and were designed to appeal to a rural audience. Tatar was also rarely used in the industrial and service economy, where prevailing language norms ensured that the presence of any non-speakers of Tatar would require Tatar-speakers to shift to Russian even in private conversations.

As of the late 1980s, it was gradually losing ground in the areas of intergenerational language transmission (stage 6), widespread literacy (stage 5), and use in lower education (stage 4). At the same time, Tatar had clearly not reached GIDS stages 7-8, where intergenerational language transmission is almost entirely lost. In rural areas,

\footnotetext{
${ }^{6}$ The occasional Tatar-speaking government employee could reply to questions in Tatar, but given that almost all Tatars spoke Russian, such situations occurred rarely if at all.
} 
the language was secure in all three intermediate stages, with Tatar language education, available through the high school level, guaranteeing literacy, and the combination of native language education and a predominantly Tatar linguistic environment ensuring intergenerational language transmission. Given the almost total elimination of Tatar language education from urban areas, Tatar had largely disappeared from stage 4 there. Tatar literacy (stage 5) was still common among older urban residents, who had either received their education in Tatar in the 1970s or earlier or had migrated to the cities from rural areas. Finally, the oral transmission of Tatar to younger generations in urban areas, while not completely eliminated, was in great danger, as about one third of Tatars spoke Russian exclusively with their children and almost half of Tatar youth never spoke Tatar amongst themselves.

The survey data discussed in this section thus shows that prior to the commencement of Tatarstan's language revival program, the Tatar language was relatively secure among rural Tatars, but in decline among Tatarstan's urban population. More urban Tatars were fluent in Russian than in Tatar and even those who spoke Tatar fluently were at least as likely to use Russian to speak to their coworkers and their children. The future of the language also seemed relatively bleak, as urban Tatar children were being educated almost entirely in Russian and spoke Russian almost exclusively amongst themselves.

\section{The Tatarstan Language Revival Program and its Implementation}

Given the extent to which Russian had displaced the Tatar language, Tatar cultural and political elites were united in their desire to reverse the decline in the use and status of the Tatar language. The republic's leaders took concrete measures to spur the 
revival of Tatar, including expanding the reach of Tatar education, mandating the equal use of Tatar in government, and promoting Tatar language use in the public sphere. In terms of the GIDS language revival scale, most of the revival effort was focused on stages 4 and 5 (education and literacy) and stages 1 and 2 (use in government and media). Relatively little effort was devoted to ensuring language revival in private business (stage 3). Both Tatar and Russian inhabitants of the republic by and large accepted this program, although some Russian activists expressed concern about the potential for discrimination based on language knowledge.

\section{The Revival of Tatar education}

The government's efforts to revive the Tatar language were initially focused on increasing the number of Tatar children who received their primary and secondary education in Tatar. While the percentage of Tatar children being educated in Tatar language schools had been as high as 70 percent as recently as 1970, by 1990 it had dropped to 24 percent, and was only three percent in urban areas. Sociolinguistic studies of language use in Tatarstan had showed that Tatar children educated in Russian were far less likely to be fluent in Tatar than their Tatar-educated peers and tended to speak Russian in most contexts. (Sharypova 1989) For this reason, Tatar leaders decided that if they wanted to ensure the survival of Tatar as a language of mass communication in the republic, restoring Tatar language education had to be their top priority. After the adoption of the republic’s sovereignty declaration in 1990, the proportion of Tatar children educated in Tatar-language schools grew at a rate faster than at any time since the establishment of mass public education in the 1920s. Between 1990 and 2001, the proportion of Tatar students who study all subjects in Tatar increased from 24 percent to 
49.3 percent and is continuing to rise. The fastest increase, from 28.5 to 41 percent, occurred between 1992 and 1994. Whereas by the end of the Soviet period, Tatar schools were virtually nonexistent in urban areas, with only 3 percent of urban students being educated in Tatar in 1990, by 199528 percent of them were receiving a Tatar language education. ${ }^{7}$ The change in Kazan is particularly striking, with over half of Tatar students being educated in Tatar by 1998. (Akhmadeev 1999, 49) While many new Tatar schools were opened in cities during the 1990s, a large part of the increase in the percentage of Tatar children attending Tatar-language schools is the result of the established of mixed Russian/Tatar language schools through the creation of Tatar-language streams in what were previously purely Russian language schools. Similar changes occurred in education for younger children, with 70 percent of Tatar children attending Tatar language preschools and kindergartens in 1999, up from 23.5 percent in 1992. (Khadiullin 1999, 62)

At the same time, Tatar officials responsible for education were not fully satisfied with the increase in Tatar language education. Some complained that just over half of Tatar schoolchildren continued to attend Russian-language schools. The greatest challenges to increasing Tatar-language education included the dearth of qualified teachers with the necessary knowledge of the Tatar language and the lack of Tatarlanguage textbooks. In both cases, math and science were particularly affected. (Aminova 1999) Furthermore, officials complained about the difficulty in convincing parents to send children to Tatar language schools because many parents believed that their children's career prospects would be damaged by an insufficient command of the Russian

\footnotetext{
${ }^{7}$ Republic of Tatarstan Ministry of Education Data.
} 
language while Tatar is not a particularly useful language outside of the village.

(Sagdeeva 2003, 89)

Officials believe that the only way to change this perception is to expand Tatar language higher education. Prior to 1991, higher education in Tatarstan functioned almost exclusively in Russian, with the Kazan Pedagogical Institute’s Faculty of Tatar Filology serving as the only exception. Graduates of Tatar language schools were at a disadvantage in having to pass entrance exams in Russian to gain admittance to these universities. After the republic's language law was passed in 1992, students applying to Russian-language universities were allowed to take their entrance exams in Tatar, largely resolving this problem. However, Tatar leaders still sought to expand the range of instruction offered in Tatar.

The opening of the Tatar State Humanities Institute in 1996 provided an impetus for other universities to offer instruction in Tatar. In the following years, all pedagogical institutes and most other universities opened sections with instruction in Tatar, although only about 10 percent of the total number of students was enrolled in these sections. In Kazan, university-level instruction in Tatar remained limited to the Tatar department of the Pedagogical Institute, and the Tatar and Journalism departments of Kazan State University. Furthermore, instruction in the sciences and in technical fields remained almost entirely the domain of Russian language instruction, with only a few exceptions in three or four universities, primarily the Kazan Architectural-Construction Academy. As of 1998, only about 1000 students were being educated in Tatar in the technical and scientific fields. Tatar academics and cultural elites hope that the eventual establishment of a Tatar State National University would eliminate this gap by establishing a high quality university that would provide a complete education in the Tatar language in any 
field. The Tatarstan parliament ordered in 1997 that such a university should be established by the year 2000. (Minnullin and Sharifullina 1999, 49) However, given the lack of funding and the extent to which higher education is controlled by the central government in Moscow, such a university is unlikely to be established in the near future. (Khasanova and Minnullin 1999, Badrutdinova 2002, Bairamova 2001, 54)

Tatar officials and scholars have argued that Tatar will not achieve fully equal status with Russian in the republic as long as all Tatars speak the Russian language but virtually no Russians speak Tatar. To end this asymmetrical bilingualism, the Tatarstan government introduced Tatar language, literature and history as required subjects in all of the republic's schools. Prior to 1993, virtually no non-Tatar schoolchildren studied the Tatar language. Ministry of Education study plans introduced at that time called for 4-5 hours/week of Tatar language instruction in all grades in all Russian-language schools. Tatar-language schools were to devote 7 hours/week to Tatar in early grades and 4 hours/week in high school. All schoolchildren in the republic were furthermore required to devote one hour/week in grades 5, 8 and 9 to the history of Tatarstan and its people. ${ }^{8}$ The implementation of these plans was to be overseen by assistant directors for national education, who were assigned to each Russian-speaking and mixed Tatar-Russian school in the republic. (Graney 1999, 617)

Once introduced, the Tatar language requirement quickly became part of the curriculum in almost all republic schools. By 1995, 92 percent of schoolchildren in Tatarstan were studying the Tatar language. This number went up to 98 percent by 1998 and has since reached 99.1 percent. (Bairamova 2003, 183) The main limitation on extending Tatar language instruction to all Russian language schools proved to be a

\footnotetext{
${ }^{8}$ Vestnik Ministerstva Narodnogo Obrazovaniia Respubliki Tatarstan, August 1993: 10, 51-55.
} 
shortfall in qualified teachers of Tatar language and literature. Many of the teachers initially sent to teach Tatar in Russian-language schools were not qualified as language teachers, but were simply teachers of other subjects who happened to speak Tatar. The quality of instruction in many of these schools in the early years of the program consequently left much to be desired. The government recognized the problem and estimated that the introduction of mandatory Tatar language classes in all of the republics schools required the training of almost 5000 additional teachers. Although the increase in the number of Tatar language sections in the republic's pedagogical institutes and other institutions of higher learning covered most of this shortfall, the problem was not expected to be completely resolved until 2005. (Aminova 1999, 100)

All of these innovations are based on principles that were first developed in the "Plan for the development of Tatar education" and then enshrined in the republic's language and education laws. The education law describes the philosophy and purpose of Tatar ethnic education as follows, "The activity of Tatar ethnic educational institutions is directed toward the revival of individual ethnic consciousness, based on the priority of common human values. In Tatar ethnic educational institutions, education is based on the Plan for the Development of Tatar Education.” The formulation of this plan began as early as 1989. The Education Ministry approved it in 1991. Its basic principles state that the educational process must be based on the idea of Tatar national rebirth, that each child is part of the future of the nation, that education and ethnic upbringing are part of a single process, that education should occur in the child's native language, and that a Tatar environment needs to be fostered in all Tatar schools. The plan calls for the creation of a special state fund for the development of Tatar schools, which should receive priority in funding until they reach the level of development of ethnic schools in the former union 
republics of the Soviet Union. The plan also provides for mandatory Tatar language instruction for Russian children. ${ }^{9}$ This provision was codified in article 10 of the language law and article 6 of the education law, which require that Russian and Tatar be studied in equal measure in all schools and kindergartens in Tatarstan. ${ }^{10}$

Because of the revival program, cultural activists and the government made significant progress in solidifying the Tatar language's position in public education at the primary and secondary school level. The adoption and successful implementation of a requirement that all students attending public schools study the Tatar language was designed to ensure widespread basic literacy in the language (GIDS stage 5).

Furthermore, whereas Tatar language education was almost entirely absent from urban areas in 1990, ten years later more than a third of ethnically Tatar children living in urban areas were receiving their education in Tatar. In this way, the government moved toward ensuring the widespread presence of Tatar education throughout Tatarstan (GIDS stage 4).

Expanding the use of Tatar in government and the public sphere

After education, the most significant efforts in Tatar language revival were focused in large part on restoring (or introducing) Tatar language use in government and the media (GIDS stages 1-2). The legal basis for promoting the use of the Tatar language in the public sphere began with the adoption of a language law in July 1992. After heated argument, the parliament rejected the idea of making Tatar the republic's sole state language, instead giving it and Russian equal rights. Nonetheless, the law significantly

\footnotetext{
${ }^{9}$ Panorama, \#8, 1991: 15-30.

${ }^{10}$ Vedomosti Verkhovnogo Soveta Tatarstana, June 1992; Vedomosti Verkhovnogo Soveta Tatarstana, October 1993.
} 
increased the status of the Tatar language, requiring that the government conduct its business and publish its laws in Tatar as well as Russian. The courts, media, industrial enterprises, public transport, and scientific and cultural institutions were also required to use both languages in conducting their affairs and in interacting with the public. The law mandated the formulation of a program for the preservation and development of the Tatar language that was to include opening Tatar language kindergartens, broadening Tatarlanguage education, expanding Tatar publishing and television and radio broadcasting, and translating important non-Tatar works of literature into Tatar and Tatar literature into Russian. ${ }^{11}$

The implementation of this law began slowly. Many of the key provisions were designed to be implemented over a 10-year period. Some of the others foundered due to lack of qualified specialists and financial problems. Nonetheless, a report on the law's implementation in Naberezhnye Chelny, Tatarstan's second largest city, found that the city government was conducting business in both languages, taking measures to expand Tatar-language education, and increasing access to Tatar language materials in city libraries. The picture looked far less rosy outside the state sphere. Most industrial and commercial enterprises, the report found, had made no effort to conform to the language law and were continuing to conduct business exclusively in Russian. ${ }^{12}$

To speed up implementation, in the summer of 1994 the Supreme Soviet adopted the State Program for the Preservation, Study, and Development of the Languages of the Peoples of the Tatarstan Republic. Despite its name, this program is almost entirely devoted to the preservation, study, and development of a single language, Tatar. Of the

\footnotetext{
11 “Law on Languages,” Vedomosti Verkhovnogo Soveta Tatarstana, \#6 1992: 3-10.

${ }^{12}$ Vedomosti Verkhovnogo Soveta Tatarstana, \#6-7, 1993: 46-48.
} 
126 points in the program, 67 are devoted explicitly to Tatar. Another 26 do not mention Tatar but in light of existing conditions can be assumed to address it primarily. Only 33 points address all of the languages spoken in Tatarstan in equal measure and none address Russian exclusively.

The program addresses all aspects of language revival. Some of its most important recommendations include the creation of a list of professions which will require the knowledge of both state languages, a 15\% salary bonus for workers in these professions who know both languages, the creation of facilities in places of work and study and in clubs for the study of Tatar, the expansion of Tatar-language education at all levels, the opening of a Tatar national state university, and the expansion of all forms of Tatar-language publication and media. ${ }^{13}$

This program led to a rapid increase in the spread of Tatar throughout public life. Tatar language classes for adults were introduced in the republic's larger cities. These classes were primarily designed for Russians and Tatars with little to no ability to speak Tatar and were supplemented with newspaper columns and short television programs designed to assist people studying Tatar on their own. Synchronous translation became available for parliamentary debates. Bilingual street signs are now ubiquitous and public transport drivers frequently make announcements in both languages. ${ }^{14}$ A 1998 law required all products sold in the republic to have descriptions and ingredients listed in both Russian and Tatar. (Minnullin and Sharifullina 1999, 55-6) Several new Tatarlanguage journals and newspapers are now available, including children's periodicals. Radio and television broadcasting in Tatar has increased by several hours per week.

\footnotetext{
${ }^{13}$ Vedomosti Verkhovnogo Soveta Tatarstana,\#8-9, 1994: 3-19.

${ }^{14}$ Interviews and personal observation during research trips in 1995, 1996, 1998 and 2002.
} 
(Iusupov 2000, 211) Traditional Tatar place-names are replacing Russian and Soviet ones throughout the republic. (Garipova 1993, 214) The results of this campaign for Tatar revival can be seen in an increase in Tatar usage outside the home, both on the street in private conversation and at school and work. ${ }^{15}$

At the same time, officials in charge of the language revival program remain dissatisfied with many aspects of its progress. They note that many decisions and laws are obeyed only superficially. While Tatar and Russian are supposed to have equal status in the conduct of government business, in reality all official documents are composed in Russian and are then translated into Tatar for publication. Although government workers and teachers who speak both Russian and Tatar receive a 10-15 percent salary increase, few Russians have chosen to learn Tatar as a result. Most of the facilities for adult learning of the Tatar language that were opened in the early 1990s have closed due to lack of interest and most Russians think that the salary bonus is just a way for the government to favor ethnic Tatars (most of whom are bilingual) over Russians. (Ganiev 2000, 364-5) Commercial enterprises have made few efforts to ensure the availability of Tatar speakers for contact with customers who would prefer to speak Tatar. But despite the officials' frustration with the slow pace of some aspects of Tatar language revival, both the status and the range of functions of the language are much higher than they were fifteen years ago.

\section{Attitudes toward the Tatar language revival program}

Efforts to increase the status of the Tatar language and to stem the decline in its use among the Tatar population received broad support among both Tatar and Russian

\footnotetext{
${ }^{15}$ Personal observation and Sharypova 1993, 194.
} 
inhabitants of the republic. Furthermore, a large number of Tatarstani Russians quickly came to support the notion that ethnic Russians living in Tatarstan should make an effort to learn the Tatar language.

Not surprisingly, support for ensuring the continued use of the Tatar language was very strong among Tatars. Surveys conducted during the 1990s showed that approximately 80 percent of Tatars believed that Tatar children should study the Tatar language in school. A similar share of the Tatar population wanted their own children to be able to speak Tatar. At the same time, most Tatars accepted the dominant role of the Russian language in their society and sought only to give the Tatar language a similar status, rather than elevating Tatar at the expense of Russian. Only about 20 percent thought that Tatar should be the sole state language in the republic, whereas about 72 percent believed that there should be two state languages. Just under 90 percent thought there all state workers should be able to speak both Tatar and Russian, while over 90 percent thought the president of the republic should speak both languages.

(Gabdrakhmanova 2002, Iskhakova 2002) The consensus for bilingualism among the Tatar population made the language revival program an easy sell among the republic's titular inhabitants.

Tatar politicians were more concerned about potential opposition toward Tatar language revival among the ethnic Russian population, who had for decades gotten by without learning any Tatar and who had the negative example of anti-Russian language policies that had been introduced in the Baltic States even before the break-up of the Soviet Union. But while some Russian activists did oppose efforts to introduce the mandatory study of Tatar in Russian schools and spoke out about the potential consequences of mandatory bilingualism in certain professions, the vast majority of 
Tatarstan's Russian population accepted the policy of two state languages promulgated by the republic's government. This change of opinion came early in the revival process. Thus, support among Russians for the study of both languages in school rose from 13 percent in 1990 to 61 percent in 1993 and has hovered around the 60 percent mark ever since. A 1997 survey showed that 70 percent of urban Russians and 92 percent of rural Russians wanted their children to learn to speak Tatar. ${ }^{16}$ (Gabdrakhmanova 2002, Iskhakova 2002) About 43 percent of urban Russians surveyed in 1990 wanted to learn Tatar themselves and similar percentage believed that Russians should be able to speak Tatar in a 2001 survey. Acceptance of official bilingualism also reached high levels, with over 70 percent of Russians supporting the idea that state workers must speak both Russian and Tatar, according to surveys carried out in 1993 and 2001. ${ }^{17}$ (Gabdrakhmanova 2002, Iskhakova 2002)

\section{Tatar Language Revival in the GIDS Framework}

Given the high levels of support among both Russians and Tatars for bilingualism in the republic, it is not surprising that the government was able to implement a fairly extensive language revival program during the 1990s. Compared to the status of the language at the dawn of perestroika, the government and cultural activists made significant progress in reviving the Tatar language. Prior to the adoption of the revival program, Tatar was almost unused in government, higher education, or linguistically mixed work environments, and had a fairly limited presence in local media (GIDS stages 1-3). It was also retreating in the spheres of education (stages 4-5) and in

\footnotetext{
${ }^{16}$ This percentage has declined in subsequent surveys, to 60 percent among the entire Russian population in 1999 and 50 percent in 2001. (Iskhakova 2003)

${ }^{17}$ An even higher percentage, 77 percent in 1993 and 83 percent in 2001, believed that the president of the republic should speak both languages. (Iskhakova 2003)
} 
intergenerational language transmission (stage 6). The revival effort focused in large part on restoring (or introducing) Tatar language use in government and the media (stages 12) and in education (stages 4-5), with the hope that these efforts would increase Tatar language use and stop the erosion of intergenerational language transmission. The revival program was quite successful in reversing language shift in those areas on which it directly focused and in changing popular attitudes toward greater support for the use of Tatar in various contexts.

However, greater support for bilingualism and even an increase in the range of functions of the Tatar language did not necessarily translate into changes in linguistic behavior among members of either ethnic group. In the next section, I will examine the extent to which this language revival program has succeeded in its primary aim of increasing the proportion of the population that knows Tatar and actively uses it in various contexts.

\section{The Failure of GIDS Stage 6 Revival: Continuing Decline in Tatar Language Use among Tatars}

Despite government officials’ successes in implementing a language revival program during the 1990s, the percentage of Tatars using the Tatar language continued to decline throughout this period. Low levels of language competence and use were particularly endemic among younger Tatars, indicating the continuing erosion of intergenerational language transmission, especially in urban areas. The proportion of Tatars who considered Tatar to be their native language remained relatively unchanged at 
88.3 percent, including 96.4 of rural and 84 percent of urban Tatars. ${ }^{18}$ (Iskhakova 2002,

28) At the same time, a 2000 survey showed that one-fifth of Tatar youth considered both

Russian and Tatar as their native languages, while 72 percent listed only Tatar and the remaining eight percent listed only Russian. ${ }^{19}$ (Zinurova 2002, 94) Given the likelihood that survey questions about native language significantly overstate language competence due to the connection between language and ethnicity, the percentage of Tatars that consider Tatar to be the language they speak best may be a better measure of the extent of ability to speak Tatar. The 2000 survey of Tatar youth showed that only 20.5 percent of Tatars under age 30 speak Tatar better than they speak Russian, with an additional 42.9 percent declaring that they speak both languages equally well, and 36.6 percent being more fluent in Russian than in Tatar (Zinurova 2002, 94)

Speaking ability among Tatars had, if anything, declined in the years since the start of the language revival program. ${ }^{20}$ While complete 2001 data for urban Tatars is not available, published results from this survey indicate that only 58.8 percent of urban Tatars are completely fluent in the Tatar language, as compared to 65.1 percent in 1990. A similar decline is registered among rural Tatars, of whom 91.6 percent considered themselves able to speak, read and write in Tatar in 2001, as compared to 97.4 percent in 1990. (Iskhakova 2002, 30) The use of Tatar also continued to erode during the 1990s, with the percentage of Tatars using the Russian language at work increasing from 35 to

\footnotetext{
${ }^{18}$ Unlike the 1990 survey, the 2001 survey did not give "both Tatar and Russian” as a response option. Without this option, the percentage of respondents who listed Russian as their native language increased from 3.9 to 8.8, while those who listed Tatar increased from 85.7 to 88.3 percent. This survey was based on a representative sample of the adult population of Tatarstan.

${ }^{19}$ This survey sample included 1000 inhabitants of Tatarstan aged 15-29.

${ }^{20}$ Some of this decline may be attributed to the aging of the population. Older urban residents with high Tatar competence who have died since 1990 have been replaced by younger generations with less competence in Tatar. This phenomenon cannot explain all of the decline, however. Furthermore, if language revival efforts were being successful, the youngest generations would show higher levels of Tatar competence, compensating for the deaths of the oldest generations. See the data on Catalonia, below, for an example of this process at work.
} 
43.5 percent while the percentage of respondents who used either Tatar or both languages declined. The percentage of urban Tatars using Tatar exclusively at home also declined, from 48 percent in 1994 to 36 percent in 2001, while the proportion using Russian increased from 22 to 24 percent and those using both languages went from 30 to 38 percent. Tatar language use declined even among rural Tatars, who went from 98.6 percent Tatar speaking at home in 1994 to 89.8 percent in 2001. At work, the decline was even steeper, from 92 percent in 1994 to 69.5 percent in 2001 (table 4).

Table 4. Primary speaking language (2001 survey)

\begin{tabular}{lrrrr}
\hline & \multicolumn{2}{c}{ Urban } & \multicolumn{2}{c}{ Rural } \\
\hline & At home & At work & At home & At work \\
\hline Tatar & 36.1 & 9.6 & 89.8 & 69.5 \\
Both & 37.1 & 41.5 & 4.8 & 13.8 \\
Russian & 24.3 & 43.5 & 3.0 & 12.0 \\
\hline
\end{tabular}

Source: Iskhakova 2002, 31.

After ten years, the increase in Tatar language education for ethnic Tatars has not had an appreciable impact on Tatar language use among Tatar youth. The majority of Tatars under age 30 use Russian when speaking with friends and when reading, while usage in the home is almost evenly split between Tatar, Russian and both equally (table 5). Given that surveys in the mid-1990s showed more than half of the Tatar youth speaking Tatar at home, it appears that Russian is continuing to make inroads among Tatar children in both rural and urban areas.

Table 5. Preferred language among Tatars under age 30 by context (2000)

\begin{tabular}{lrrr}
\hline & At home & With friends & Reading \\
\hline Tatar only & 20.7 & 6.9 & 3.9 \\
Mostly Tatar & 15.6 & 8.7 & 4.5 \\
Tatar and Russian equally & 35.9 & 37.2 & 35.0 \\
Mostly Russian & 19.1 & 32.4 & 29.7 \\
Russian only & 8.7 & 14.6 & 26.4 \\
\hline Sol
\end{tabular}

Source: Zinurova 2002, 99, 104, 106. 
The Tatar linguistic revival program has not been entirely fruitless in affecting language knowledge and use in Tatarstan. The introduction of mandatory Tatar language classes for all schoolchildren has been effective in increasing Tatar language knowledge among that part of the population that does not study in Tatar schools. Surveys show a substantial increase in the number of Russians with at least some knowledge of the Tatar language, although the total number of Russian fluent in Tatar is still quite tiny. The total percentage of urban Russians with at least some ability to speak Tatar almost doubled, from 6.2 percent in 1990 to 12.3 percent in 2001. The percentage of urban Russians who can understand Tatar but cannot speak it also increased, from 12.1 to 16.8 percent. (Gabdrakhmanova 2002, 121) The extent of Tatar language knowledge is even greater among Russian youth, of whom 22 percent can speak Tatar at some level and an additional 21 percent can understand Tatar but do not speak it. (Gabdrakhmanova 2002, 121) This is not surprising, given that few Russians have studied Tatar in the last fifteen years outside of school.

The increase in Tatar language knowledge among Russians thus appears to be the direct result of the language revival program. Prior to the 1990s, most Tatarstani Russians had no opportunity to learn Tatar, since it was not offered in Russian schools and the government did not encourage its study. The language revival led to a huge increase in the opportunities available to Russians for Tatar language study. Furthermore, some Russians have sought to learn some Tatar because they believed that knowing the language would benefit their career prospects. ${ }^{21}$ In other words, given the minuscule number of Russians who spoke Tatar prior to the start of language revival, the benefits of

\footnotetext{
${ }^{21}$ Most Tatars who rarely used the Tatar language nonetheless knew it sufficiently well to get a job that required some knowledge of both languages, so this new incentive did not significantly change their calculus in deciding which languages to study.
} 
being one of the early adopters of the Tatar language were sufficiently high that a number of Russians learned the language once the opportunity to do so presented itself. However, Russians who have learned Tatar rarely use it in public contexts, except when they want to keep information secret from Russian monolinguals. Most of them also have a fairly low level of linguistic competence. ${ }^{22}$ The Russians who have learned Tatar in the last fifteen years have done so largely for pragmatic reasons and this knowledge has not led to changes in their linguistic behavior.

\section{Why failure?: A comparative explanation}

The virtual impossibility of enacting policies that directly impact individual language choices is the greatest difficulty faced by language revival programs. While the goal is usually to increase the number of speakers and the range of contexts in which these speakers use the endangered language, language revival policies focus on improving the status of the language by increasing its use in government, education, the media, and the workplace. The hope is that if people have more opportunities to learn the language and feel that the language is undergoing a revival, they will be more likely to learn it and to use it.

The primary goals of Tatarstan's language revival program were to ensure that Tatar language use increased in the public sphere and that the next generation of Tatars continued to use the Tatar language as their primary means of communication. The program proved to be moderately successful in expanding the use of Tatar in the public sphere but unsuccessful in reversing the trend toward a decrease in Tatar language

\footnotetext{
${ }^{22}$ Unfortunately, little survey or observation data is available on the extent of Tatar-language competence among Russians in Tatarstan for the last decade. My conclusions are based on informal personal observations during repeated visits to the region from 1995 to 2002.
} 
knowledge and use among ethnic Tatars. The majority of the resources devoted to cultural issues in Tatarstan during the 1990s were devoted to expanding education in the Tatar language at all levels, increasing the use of Tatar in government offices and in the public sphere, and replacing Russian language signs with bilingual ones throughout the republic. Increasing knowledge of Tatar among the republic's Russian population was a secondary goal that did not receive nearly as much attention. The Tatar language classes for adults that were started in the early 1990s disappeared almost immediately. Plans to require members of certain professions to speak both languages remained incomplete for over a decade. Tatar language classes were made mandatory for all schoolchildren, however. And this last effort proved to be the only part of the Tatar language revival program that had an appreciable impact on language use and knowledge patterns in the republic a decade after the revival began.

How do the results of Tatarstan's language revival program compare to regions in other parts of the world where regions whose languages were under threat from languages supported by an independent state have made efforts at linguistic revival? While a full comparative study is outside the scope of this article, some preliminary comparative observations from Spain and Wales may help us in explaining why language use and knowledge in Tatarstan has continued to decline despite the significant improvement in the language's status and range of functions.

The Spanish cases of Catalonia and Euskadi (the Basque Country) are particularly relevant. Spain, like the Soviet Union, was for several decades a repressive state that sought to replace regional languages with the national language. To this end, Castillian Spanish was the only language the Franco government allowed to be used in the classroom and in government. Also, like in the Soviet Union, wealthy minority regions 
attracted large numbers of immigrants, most of whom belonged to the majority linguistic group. In both cases, the immigration largely stopped at the beginning of the democratization period. Finally, as in Russia, the end of the dictatorship allowed regional cultural and political leaders to enact linguistic revival programs beginning in the late 1970s, which were particularly far-reaching in Catalonia and Euskadi.

The 1983 Catalan language law required Catalan school instruction for a minimum of two subjects and encouraged all schooling to gradually shift to instruction in Catalan. The ability to pass a Catalan language exam became a high school graduation requirement for all students. Schooling was not segregated by ethnicity or mother tongue, with all children in a particular neighborhood studying together. Furthermore, Catalan immersion programs were started in predominantly Castillian neighborhoods. These programs could be implemented despite the constitutional requirement that all children be guaranteed an opportunity to be educated in their native language because Castillianspeaking parents wanted their children to learn Catalan and were willing to enroll them in Catalan-speaking schools. (Webber and Strubell 1991) The language revival program also extended to the government and the media. Whereas in the late 1970s very few civil servants could speak Catalan, by the mid-1980s Catalan became the exclusive language in parliament, all laws were written in Catalan, and regional government officials always spoke Catalan in public. The government began a serious effort at providing languagetraining courses for civil servants, although Castillian continued to be used in regional branch offices of the central government, as well as in the army, police and judiciary. (Siguan 1993, 154-6) At the same time, the government established Catalan-language television and expanded Catalan radio broadcasting. (Mar-Molinero 1989) 
The 1997 language law went even further, stating that all official forms and documents would be issued only in Catalan, and would only be made available in Castillian upon request. Admission to the Catalan civil service required oral and written fluency in Catalan. Firms receiving subsidies from the regional government were required to interact with that government exclusively in Catalan. Finally, Catalan language quotas were introduced for film, radio, and private television broadcasting. (Roller 2001, 46) The focus throughout the two decades of language revival implementation was on ensuring the freedom of Catalan-speakers to use Catalan in any and every context, even if measures to ensure this freedom were taken at the expense of the rights of Castillian monolinguals to employment in government, education and the media.

The results of the Catalan language revival program in increasing language knowledge and use were impressive and appeared quickly after the commencement of the program. The ability to understand Catalan increased from 81 percent in 1981 to 90 percent of the population in 1986 and 95 percent of the population by 1996. Speaking, reading and writing abilities rose more gradually (Table 6). The impact of the education program on knowledge of Catalan is shown by the high rates of Catalan knowledge among 15-29 year olds, who were 15 percent more likely to know Catalan than 30-44 year olds, and 27 percent more likely than 45-64 year olds (Strubell 2000, 276). Overall use of Catalan has also increased, with linguistically-mixed couples now four times more likely to raise their children in Catalan or bilingually than solely in Spanish (Strubell 2000, 278).

Table 6. Linguistic Ability in Catalan (percent)

\begin{tabular}{lrrrrr}
\hline & 1981 & 1986 & 1991 & 1996 & 2001 \\
\hline Understand & 81 & 90.3 & 93.8 & 95.0 & 94.5 \\
\hline
\end{tabular}




\begin{tabular}{lrrrrr}
\hline Speak & 64 & 64.0 & 68.3 & 75.3 & 74.5 \\
Read & 61 & 60.5 & 67.6 & 72.4 & 74.3 \\
Write & 32 & 31.5 & 39.9 & 45.8 & 49.8 \\
Don’t understand & 19 & 9.4 & 6.2 & 5.0 & 5.5 \\
\hline
\end{tabular}

Source: Catalan census data. http://www.idescat.net/en/poblacio/poblcensling.html

While the Basque region was even wealthier than Catalonia, it was more similar to Tatarstan in that the Basques had a lower status than immigrant Castillians. Furthermore, the Basque and Castillian languages were completely unrelated. Both of these factors made the linguistic environment in Euskadi prior to the start of the revival program quite similar to that found in Tatarstan. In 1975, only 40 percent of the nativeborn Basque population understood Basque, while 30 percent could speak it. (Clark 1981) The language revival program in the region was not as extensive as that of Catalonia. While all schools were required to teach the Basque language, it initially became the language of instruction only in a minority of schools. ${ }^{23}$ While new civil servants were required to pass a Basque language exam, the government essentially continued to function in Castillian, with the only exception being found in the language and culture departments (Siguan 1993, 217-18). Despite the limits of the language revival program in Euskadi, about half of respondents in a 1986 survey thought that knowledge of Basque helped in finding work, while almost two-thirds thought that Basque-speakers had better jobs than Castillian monolinguals (Fishman 1991, 173).

Although the initial linguistic situation was not very favorable for Basque and the linguistic revival program in Euskadi was not as extensive as that of Catalonia, Basque language knowledge and use has nevertheless increased substantially in the region over the last two decades. The percentage of the population who consider themselves Basque-

\footnotetext{
${ }^{23}$ In 1986, 20 percent of public schools taught entirely in Basque, and an additional 16 percent taught some subjects in Basque. Basque language education did become dominant over the next decade, and by 1998, 45 percent of schools taught entirely in Basque, while a further 28 percent taught in both languages (Lasagabaster 2001, 411).
} 
speakers has increased from 21.6 percent of the population in 1981 to 32.3 percent in 2001. Partial speakers also increased, from 14.5 percent to 23 percent, during this time period. (Table 7) Most interestingly, the percentage of respondents who declared Castillian to be their mother tongue who consider themselves fluent in Basque increased from 4.7 percent in 1986 to 14.6 percent in 2001. This shows that the Basque language is, for the first time, beginning to make some inroads among the Castillian immigrant community. The use of the Basque language among those fluent in it has also increased, although to a smaller extent. Surveys using direct observation of language use show that the percentage of the population using Basque in their everyday communication has increased from 7.6 percent in 1989 to 10 percent in 1997. Furthermore, the highest values and fastest rates of increase in Basque language use were found among children and young adults (Lasagabaster 2001, 405).

Table 7. Basque language knowledge (percent)

\begin{tabular}{llllll}
\hline & 1981 & 1986 & 1991 & 1996 & 2001 \\
\hline Basque-speakers & 21.6 & 24.6 & 26.3 & 30.9 & 32.3 \\
Partial speakers & 14.5 & 17.4 & 19.8 & 19.7 & 23.1 \\
Spanish monolinguals & 64.0 & 58.0 & 53.9 & 49.4 & 44.6 \\
\hline
\end{tabular}

Source: Basque census data. http://www.eustat.es/bancopx/spanish/indice.asp

The Welsh language has been undergoing a gradual revival since the late 1960s. Prior to that time, the Welsh language was in a classic state of diglossia, with the local elite having adopted the English language and the Welsh language having been relegated exclusively to private realms and associated with backwardness. The 1870 Education Act explicitly prohibited Welsh language from being used in Welsh schools. The result was a gradual retreat of the Welsh language into the marginal northern and western rural parts of Wales and the complete disappearance of Welsh monolinguals (May 2000, 104-5). 
The percentage of the population of Wales able to speak Welsh declined from 50 percent in 1901 to 21 percent in 1971 (Aitchison and Carter 1985, 8, 20).

The Welsh revival began in the 1960s, when, after a long campaign by the Welsh nationalist political party Plaid Cymru, the British government established the Welsh Office to govern the region. This was followed by the Welsh Language Act of 1967, which guaranteed equal status for English and Welsh in Wales. More specifically, this Act "permitted the use of Welsh in courts, giving the right to trial in Welsh or interpretation where appropriate, made contracts drawn in the Welsh language equally enforceable with those drawn in English, and permitted various other interactions with Government such as company registration and television and driving licencing to be made in Welsh." ${ }^{24}$ The subsequent language revival effort included a public campaign for public broadcasting in Welsh, which culminated in the establishment of Radio Cymru in 1977 and a Welsh-language television channel in 1982, and an effort to enact legislation to allow individuals to use Welsh in all dealings with the government and other public bodies (Smith 2000, 337). The 1993 Welsh Language Act not only guaranteed such a right, but also established an official Welsh Language Board with the power to ensure the adoption of Welsh within the public sector by requiring each public organization to submit to the board a plan for how it would provide bilingual public services (May 2000, 107).

At the same time as the government was implementing measures to increase the use of Welsh in public life, Welsh-language education was also undergoing a revival. Nationalist activists opened the first private Welsh-language school in 1939 (Morgan 1988, 249). The first public school was opened in 1947 on the basis of the 1944

\footnotetext{
${ }^{24}$ http://users.comlab.ox.ac.uk/geraint.jones/about.welsh/\#country
} 
Education Act, which provided parents the opportunity to request the type of education they wanted for their children (Griffiths 1997, 41). The number of Welsh schools increased rapidly in subsequent years. By 1980, there were 54 such primary schools, with an enrolment of 9,769 pupils (Evans 2000, 365). By 1993, there had been a tenfold increase, to 538 Welsh-language primary schools, serving almost 20 percent of the total primary school population. Even further progress was made as the result of the adoption of the Education Reform Act in 1988, which recognized Welsh as a core subject in Wales and therefore required that the language become a compulsory subject of study for all students not receiving their education in Welsh (May 2000, 109-11). This legislation for the first time put Welsh and English on an equal footing in all schools in the region.

The impact of the increased status of Welsh in schools and in public life has been profound. The percentage of the population able to speak Welsh reached a low of 19 percent in the 1981 census, stayed even in 1991, and, for the first time in 100 years, rose to 21 percent in the 2001 census (Higgs et al. 2004, 195). The census also shows that 20 percent of the inhabitants of Wales can read Welsh and 18 percent of them can write the language. There has been a particularly striking increase in the percentage of Welshspeakers among the school-aged population, with 46 percent of this population now able to speak Welsh (Census 2004).

How can we explain the success of efforts to reverse language shift in Catalonia, Euskadi and Wales, and the failure of similar efforts to stem the decline in language knowledge and use in Tatarstan? Scholars of Catalan sociolinguistics have attributed the success of the Catalan linguistic revival program to several factors. They argue that, most importantly, the Catalan language benefited from the high social status of Catalanspeakers in the region. Because Catalonia was one of the wealthiest regions in Spain, it 
attracted a large number of Castillian immigrants and by 1975 about half of its population was made up of Castillians. However, native Catalans dominated its economy, whereas the immigrants tended to predominate positions in unskilled labor and other low-status occupations. Even though Castillian was the primary language in most workplaces, learning Catalan was therefore seen as a pathway to social mobility and most Castillianspeaking parents were happy to have their children learn Catalan. Furthermore, the Catalan and Castillian language were closely related, reducing the costs and time required to learn Catalan. Given the status benefits of learning Catalan and the relative ease with which the language could be learned, it is perhaps not surprising that Catalan revival policies succeeded in reversing language shift. Furthermore, the Catalan government engaged in a public campaign to encourage Castillian-speakers to learn Catalan, emphasizing that to be Catalan one simply had to learn the language and accept the identity of belonging to the region. This open identity, combined with the ease of learning Catalan for Spanish-speakers and the status and economic advantages of speaking the official language, meant that there were high incentives and low costs for Spanishspeakers to learn Catalan.

Explaining success in the Basque case is somewhat more challenging. Virtually none of the favorable factors present in the Catalan case apply to Basque. The language is quite difficult for Spanish-speakers to learn and the Basque identity is largely closed to immigrants since it is based primarily on ethnic descent, rather than region and language. The percentage of Basque speakers in the region is much lower than in Catalonia (or even in Tatarstan), and since the linguistic revival program in the region was not as farreaching as Catalonia's, there are fewer economic incentives to learn Basque. Yet the rates of Basque language knowledge have been increasing, both among ethnic Basques 
and among Spanish immigrants. The main factor appears to be the increase in the language's status in the region. For Basques, the ideology of nationalism and ethnic revival has led to a renewed focus on maintaining Basque culture, including the language. For non-Basques, the recognition that Basque is the official language of the Basque Country has, in some cases, led to a willingness to learn it. This is especially true for younger non-Basques, who are increasingly exposed to the Basque language in their schooling.

The Welsh case is in many ways similar to Basque. Welsh is a Celtic language that is quite different from English. Welsh identity is closely tied to the language and there are few incentives for migrants from other parts of Great Britain to adopt a Welsh identity. Despite the recent increase, the percentage of Welsh speakers in the region is even lower than that of Basques in Euskadi. The incentives for learning Welsh, one might argue, are greater than those for learning Basque. Since the government and public organizations provide a significant percentage of the total number of jobs in the region, government programs to promote bilingualism in the workplace have had a significant impact on the incentives for learning Welsh. At the same time, the spread of Welsh education throughout the school system over the last fifteen years has given young people easy access to opportunities to learn the language. Furthermore, societal attitudes have been broadly supportive of Welsh revival, encouraging students to study the language seriously in school (Williams and Morris 2000).

Do the Spanish and Welsh cases help us shed light on the reasons for the continuing decline of Tatar language use? Tatarstan shares some characteristics with these regions. First, the continuing pressure of the dominant Russian linguistic environment is the cause of the continued decline of Tatar language use among Tatars, 
and especially among urban youth. Although the revival program has increased the visibility (and audibility) of Tatar in public places, most of Tatarstan’s cities are still predominantly Russian-speaking zones. In large part, this is the result of simple demographics. Most of the larger cities are predominantly Russian, and Russians comprise over 50 percent of the population in Kazan. In addition to the ethnic Russians and Russian-speaking Slavs, a minority of urban Tatar adults is linguistically Russified. Altogether, about two-thirds of Tatarstan's urban population speak Russian as their primary language. This Russophone linguistic environment cannot be changed in a relatively short period of time by measures such as the introduction of Tatar language street signs and the publication of republic legislation in Tatar. The expansion of Tatar language education for children may have some impact in the long run, but it affects neither the Russophone Tatars who are already out of school nor the 50 percent of Tatar children who are still being educated in Russian language schools.

Furthermore, the Tatar case shares most of the difficulties faced by Basque and Welsh. It is in a different language family from Russian, and therefore quite difficult for Russians to learn. Tatar identity is based on ethnicity and is not open to Russian assimilation. Given the continuing dominance of Russian in both government and private employment, economic incentives for learning Tatar are quite low. This is similar to Basque, but not to Welsh. The most important difference, however, is that the status of both Basque and Welsh vis-à-vis each country’s majority language has increased greatly since the language revival began, whereas that of Tatar vis-à-vis Russian has not. Outside of the numerically small cultural elite, Tatar continues to be viewed by urban Tatars as a language most suitable for use in the home or the village, rather than in high culture, science, and government (Iskhakova 2002). 
These findings suggest that success in reversing language shift depends greatly on the extent to which cultural activists are able to increase the status of the endangered language vis-à-vis the newly dominant language. Language revival programs are unlikely to change linguistic behavior when they are undertaken in an environment where the language being revived remains subordinate to and less prestigious than another language. They may, however, encourage some members of other ethnic groups to learn the language for pragmatic reasons, such as to improve their employment prospects or to increase their status with the ruling ethnic group that is undertaking the language revival program. 


\section{References}

Aitchison, J.W. and H. Carter. 1985. The Welsh Language 1961-1981: An Interpretative Atlas. Cardiff: University of Wales Press.

Akhmadeev, F.G. 1999. "Problemy realizatsii zakonodatelstva Respubliki Tatarstan o iazykakh v g. Kazani.” Iazykovaia Situatsiia v Respublike Tatarstan: Sostoianie i Perspektivy, Chast 1. Kazan: 48-53.

Aminova, Kh.G. 1999. "Podgotovka pedagogicheskikh kadrov dlia uchrezhdenii natsionalnogo obrazovaniia respubliki.” Iazykovaia Situatsiia v Respublike Tatarstan: Sostoianie i Perspektivy, Chast 1. Kazan: 97-101.

Badrutdinova, G.G. 2002. "Problemy primeneniia tatarskogo iazyka v sfere nauki i vysshei shkoly.” Problemy iazyka, literatury, i narodnogo tvorchestva, vyp. 2. Kazan: Fiker, 115-18.

Bairamova, L.K. 2001. Tatarstan: Iazykovaia simmetriia i asimmetriia. Kazan: Kazan University Press.

Beissinger, Mark R. 2002. Nationalist Mobilization and the Collapse of the Soviet State. New York: Cambridge University Press.

Census 2004. Census 2001: Report on the Welsh Language. London: Office for National Statistics.

Clark, Robert P. 1981. “Language and Politics in Spain’s Basque Provinces.” West European Politics 4(1), 85-103.

Evans, W. Gareth. 2000. "The British State and Welsh Language Education 1914-1991.” In Geraint H. Jenkins and Mari A. Williams (eds.) Let's Do Our Best for the Ancient Tongue: The Welsh Language in the Twentieth Century. Cardiff: University of Wales Press, 343-370.

Gabdrakhmanova, G.F. 2002. "Iazykovoe iskliuchenie: prichiny i formy proiavleniia.” Iazyk i etnos na rubezhe vekov: Etnosotsiologicheskie ocherki o iazykovoi situatsii v Respublike Tatarstan. Kazan: Magarif, 110-47.

Ganiev, F.A. 2000. Tatarskii iazyk: problemy i issledovaniia. Kazan: Tatar Publishing.

Garipova, F.G. 1993. “Toponimy: sviaz proshlogo i nastoiashchego.” Mezhetnicheskie i Mezhkonfessionalnye otnosheniia $v$ respublike Tatarstan. Kazan: Office of the President, 213-15.

Gorenburg, Dmitry P. 1999. "Regional Separatism in Russia: Ethnic Mobilisation or Power Grab?” Europe-Asia Studies 51(2), 245-274. 
Gorenburg, Dmitry P. 2003. Minority Ethnic Mobilization in the Russian Federation. New York: Cambridge University Press.

Graney, Katherine E. 1999. "Education Reform in Tatarstan and Bashkortostan: Sovereignty Projects in Post-Soviet Russia.” Europe-Asia Studies 51(4), 611-632.

Grenoble, Lenore A. 2003. Language Policy in the Soviet Union. Boston: Kluwer Academic Publishers.

Griffiths, Merfyn. 1997. "The Growth of Welsh-medium Schools.” In Merfyn Griffiths (ed.) The Welsh Language in Education, Vol. 2. Cardiff: WJEC, 39-44.

Higgs, Gary et al. 2004. "Use of the Census of Population to Discern Trends in the Welsh Language: An Aggregate Analysis.” Area 36(2), 187-201.

Iskhakova, Z.A. 2001. Dvuiazychie v gorodakh Tatarstana (1980-90-e gody). Kazan: Fiker.

Iskhakova, Z.A. 2002. "Funktsionalnoe vzaimodeistvie tatarskogo i russkogo iazykov v sovremennom Tatarstane.” Iazyk i etnos na rubezhe vekov: Etnosotsiologicheskie ocherki o iazykovoi situatsii v Respublike Tatarstan. Kazan: Magarif, 13-41.

Iskhakova, Z.A. 2003. "Iazyk kak faktor stabilnosti i konfrontatsii.” Aktualnye voprosy Tatarskogo iazykoznaniia, vypusk 2. Kazan: Fiker, 112-19.

Iusupov, R.A. 2000. “Gosudarstvennye iazyki i razvitie narodov Respubliki Tatarstan.” Tatarskoe vozrozhdenie: epokha i lichnosti. Kazan: Fen, 208-13.

Khadiullin, I.G. 1999. "Realizatsiia Zakona ‘O iazykakh narodov Respubliki Tatarstan’ v obrazovatelnykh uchrezhdeniiakh.” Iazykovaia Situatsiia v Respublike Tatarstan: Sostoianie I Perspektivy, Chast 1. Kazan: 59-67.

Khasanova, G. and K. Minnullin 1999 “O iazykovoi politike v vysshem obrazovanii v Tatarstane.” In K.M. Minnullin and L.G. Sharifullina (eds.) Iazykovaia politika v Respublike Tatarstan: Dokumenty i materially (80-90-e gody). Kazan: Magarif, 32637.

Lasagabaster, David. 2001. "Bilingualism, Immersion Programmes and Language Learning in the Basque Country.” Journal of Multilingual and Multicultural Development 22(5), 401-25.

Mar-Molinero, Clare. 1989. “The Teaching of Catalan in Catalonia.” Journal of Multilingual and Multicultural Development 10(4), 307-20.

May, Stephen. 2000. "Accomodating and Resisting Minority Language Policy: The Case of Wales.” International Journal of Bilingual Education and Bilingualism 3(2), 101128. 
Minnullin, K.M. and L.G. Sharifullina (eds.) 1999. Iazykovaia politika v Respublike Tatarstan: Dokumenty i materially (80-90-e gody). Kazan: Magarif.

Morgan, Gerald. 1988. "The Place of School in the Maintenance of the Welsh Language.” Comparative Education 24(2), 247-255.

Roller, Elisa. 2001. “The 1997 Llei del Catala: A Pandora’s Box in Catalonia?” Regional \& Federal Studies 11(1), 39-54.

Sagdeeva, F. 2003. Problemy kultury tatarskoi rechi v usloviiakh aktivnogo dvuiazychiia. Kazan: Fiker.

Sharypova, N.Kh. 1989. Kultura russkoi rechi u tatar. Moscow: Nauka.

Sharypova, N.Kh. 1993. "Problema izucheniia tatarskogo iazyka v respublike." Mezhetnicheskie i Mezhkonfessionalnye otnosheniia v respublike Tatarstan. Kazan: Office of the President, 193-4.

Siguan, Miquel. 1993. Multilingual Spain. Amsterdam: Swets \& Zeitlinger.

Silver, Brian. 1986. "The Ethnic and Language Dimensions in Russian and Soviet Censuses.” In Ralph S. Clem (ed.) Research Guide to the Russian and Soviet Censuses. Ithaca, NY: Cornell University Press, 70-97.

Smith, Robert. 2000. "Broadcasting and the Welsh Language.” In Geraint H. Jenkins and Mari A. Williams (eds.) Let's Do Our Best for the Ancient Tongue: The Welsh Language in the Twentieth Century. Cardiff: University of Wales Press, 311-342.

Strubell, Miquel. 2000. “Catalan a Decade Later.” In Joshua A. Fishman (ed.) Can Threatened Languages Be Saved?: Reversing Language Shift, Revisited: A $21^{\text {st }}$ Century Perspective. Clevedon, UK: Multilingual Matters, 260-83.

Webber, Jude and Miquel Strubell i Trueta. 1991. “The Catalan Language: Progress Toward Normalization.” The Anglo-Catalan Society Occasional Publications 7.

Wertheim, Suzanne. 2003a. “Language Ideologies and the 'Purification’ of Post-Soviet Tatar.” Ab Imperio \#1, 347-369.

Wertheim, Suzanne. 2003b. Linguistic purism, language shift and contact-induced change in Tatar. University of California, Berkeley: Unpublished Ph.D. dissertation. Avaiable at http://ling.northwestern.edu/ wertheim/.

Wertheim, Suzanne. 2005. "Islam and the Construction of Tatar Sociolinguistic Identity." In B. Forest, J. Johnson and M. Stepaniants, eds. Religion and Identity in Modern Russia: The Revival of Orthodoxy and Islam. London: Ashgate, 106-123. 
Williams, Glyn and Delyth Morris. 2000. Language Planning and Language Use: Welsh in a Global Age. Cardiff: University of Wales Press.

Zinurova, R.I. 2002. "Rol rodnogo iazyka v protsesse etnicheskoi sotsializatsii molodogo pokaleniia v Respublike Tatarstan.” Iazyk i etnos na rubezhe vekov: Etnosotsiologicheskie ocherki o iazykovoi situatsii v Respublike Tatarstan. Kazan: Magarif, 88-109. 